http://dx.doi.org/10.4314/jae.v16i1.10

\title{
Responsiveness of Extension Workers to Climate Change in Anambra State, Nigeria
}

\author{
Onyeme N.F and Iwuchukwu J .C. \\ (julieiwuchukwu@yahoo.com) \\ Department of Agric Extension \\ University of Nigeria, Nsukka
}

\begin{abstract}
Given the role agricultural extension will play in sensitizing and educating farmers on how to mitigate and adapt to climate change, the study was carried out to ascertain the responsiveness of extension workers to climate change. Fifty one extension workers proportionately selected from the four agricultural zones in the state were used for the study. Data were analyzed with percentage, mean score and factor analysis. All (100\%) of the respondents had heard about climate change. On average they heard it in 2003 and noticed it in 2002. They sourced information on climate change from fellow extension workers (77.8\%) and newspapers (76.6\%). Only "giving reports with respect to climate or weather of the environment (58.8\%) was activity occurring/undertaken by extension workers with respect to climate change. Prediction/ forecasting of weather (92.2\%) was area the extension workers mostly needed training on climate change. Manpower development/training, institutional/linkage and staff incentive problems were factors constraining responsiveness of extension workers in Anambra state to climate change. The study recommends the need to acquaint extension workers with knowledge on climate change and climate related issues by including it in the programme of ADP. In this way the extension workers especially front line extension agents can educate and help farmers mitigate and adapt to the impact of climate change for increased agricultural output.
\end{abstract}

Key words: responsiveness climate change extension workers

\section{Introduction}

Indicators of climate change are temperature increases, varying rainfall patterns, more extreme weather events (for example storms, floods, droughts, and heat waves), sea-level rise, rapidly changing seasons, ocean acidification and glacial melting (Hulme, Doherty, Ngara, New, et al., 2001). The local farmers are experiencing climate change (Apata, Samuel and Adeola 2009), through the late arrival of rain, the drying-up of stream and small rivers that usually flow year round. Also, the gradual disappearances of flood-recession cropping in riverine 
areas of Ondo State are among the effects of climate disturbances in some communities in Nigeria (Building Nigeria's Response to Climate Change (BNRCC), 2008, Apata , Samuel and Adeola, 2009).

The impacts of climate change are varied. It may be physical, ecological, social or economic and evident in areas such as agriculture and fisheries, energy, water, human health, food security, biodiversity and ecosystem services, industry, human settlements and disaster management (Fischlin, Midgley, Price, Leemans, et al. 2007). Climate change is a threat to agriculture and non-agricultural development. Agricultural production activities are generally more vulnerable to climate change than other sectors. (Kurukulasuriya, Mendelsohn, Hassan and Benhin, 2006). Agriculture places heavy burden on the environment in the process of providing humanity with food and fiber, while climate is the primary determinant of agricultural productivity (Apata et al. 2009). It is evident that climate change will have a strong impact on Nigeria particularly in the areas of agriculture, land use, energy consumption, biodiversity health and water resources (Apata et al. (2009). Smith and Skinner (2002) asserted that climate plays a dominant role in agriculture having a direct impact on the productivity of physical production factors, for example the soil's moisture and fertility. Adverse climate effects can influence farming outputs at any stage from cultivation through the final harvest. Even if there is sufficient rain, its irregularity can affect yields adversely if rains fail to arrive during the crucial growing stage of the crops (Mowa and Lambi, (2007), Rudolf and Hermann 2009). Climate change is expected to influence crop and livestock production, hydrologic balance, input supplies and other components of agricultural systems (Ayanwuyi, Kuponiyi, Ogunlade, and Oyetoro, 2010).

Access to adequate information equips farmers to deal with climate variability and hence increase agricultural production. Information is an indispensable factor in the practice of farming and it is the basis of extension service delivery. Extension's major activities over time are to disseminate useful information from research to farmers and this is even more important in light of climate change and its impact on agriculture. Extension systems can help farmers deal with climate change by providing them information on causes and effects of climate change as well as adaptive and contingency measures for what cannot be prevented about climate change. Extension will also help farmers to access new technologies and management options in those areas where climate change renders their current farming systems inviable (Agwu and Adeniran, 2009).

Globally, much have been said and known about the impact of climate change on agriculture and extension role in educating and equipping farmers with information that will help them deal, cushion and adapt to climate change. Extension however can perform the above mentioned tasks when it is responding to climate change. This is because awareness and perception of a problem such as climate change help one to take timely and adequate action on it. There is then the need to investigate the responsiveness of extension workers to climate change. Specifically, the study sought to ascertain their awareness and view about climate change; identify their sources of information, training needs and activities 
occurring/undertaken by them with respect to climate change as well as ascertain constraints limiting them from responding to climate change.

\section{Methodology}

The study was carried out in Anambra state, Nigeria. It has an estimated population of 4.18 million and land area of approximately 5.025 sq.km (NPC, 2006).

The population for the study consisted of all the extension workers in Anambra state Agricultural Development Programme (ADP). The four agricultural zones (Awka, Aguata, Anambra and Onitsha zones) in the state were used for the study. Proportionate sampling technique was used to select about $50 \%$ of extension workers in each cadre and from each of the zones. Out of the 87 extension workers in the state, 51 were selected.

The four zonal managers were selected (one from each zone), three zonal extension officers were selected (one from each zone that had zonal extension officer), twelve subject matter specialists were randomly selected (three from each of the four zones), eight block extension supervisors were selected (two from each of the four zones), six block extension agents were randomly selected (two each from zones $A$ and $D$ and one each from zones $B$ and $C$, respectively) and eighteen field extension agents were randomly selected ( 5 each from zones $A, C$ and $D$ and three from zone B).

\section{Data collection}

Data for this study were obtained through the use of questionnaire.

Respondents were asked questions on their awareness, time they noticed and heard about climate change and the extent they felt that climate had changed. They were also asked to indicate their first source and other sources of information on climate change. Some of the sources listed were: fortnightly training (FNT), radio, television, meteorologists, fellow extension workers, and others.

Extension workers (the respondents) were asked to tick from the list provided and also state those activities occurring/undertaken by them with respect to climate change. Some variables listed were: extension workers organize/ attend training/ workshops/ seminar on climate and climate change, extension workers embarked on formal/certificate training on climate change/climate related courses and others.

Training needs of the extension workers were identified by listing variables like: measurement of amount of rainfall, measurement of intensity of sunshine, prediction/forecasting of weather etc. and requesting the respondents to tick from the list and also include other areas they need training on climate/climate change.

Constraints limiting extension workers from responding to climate change were achieved by using a four point Likert-type scale with response options as follows: to a great extent (4), to some extent (3), to a little extent (2), and to no extent (1). The mean was 2.5 . Any variable with a mean score higher or equal to 2.5 was regarded as a major constraint while variable with mean score less than 2.5 was regarded as minor constraint. Data were further subjected to factor analysis. 
Data were analysed with percentage, mean score and factor analysis (varimax rotation and Kaiser's normalization) ( (Comrey,(1962) in Chukwuone, Agwu and Ozor,(2006)) where variable with loading of 0.40 and above was considered as having a high loading and used to name a factor.

\section{Results and Discussions}

\section{Awareness and view of extension workers about climate change \\ First time (year) respondents heard about climate change}

Table 1 shows that all (100\%) of the respondents had heard about climate change.Greater proportion (50\%) of them heard about climate change first within 2006-2010 while those who heard it first within 1996-2000 accounted for $26.2 \%$ of the sample.

The mean year that the respondents heard about climate change first was 2003. This indicates that the respondents heard about climate change not too long ago.

\section{Respondent's view about when climate started changing}

A greater proportion of the respondents (46.4\%) revealed that climate started changing within $1998-2002,39.3 \%$ of the respondents indicated that climate started changing within 2003-2007 (Table1). About 14\% indicated that climate started changing within 1993-1997. The mean year that they perceived that the climate started changing was 2002. This shows that the respondents heard about climate change shortly after they noticed it. This experience they had before hearing about climate change will help them to appreciate climate change and information related to it.

TABLE 1

Respondents awareness and view about climate change

\begin{tabular}{lccc}
\hline Variable & Frequency & $\begin{array}{c}\text { Percentage } \\
(\%)\end{array}$ & $\begin{array}{c}\text { Mean } \\
(\mathbf{M})\end{array}$ \\
\hline Heard about climate change: & 51 & 100.0 & \\
Yes & 0 & - & 2003 \\
No & & & \\
First time heard about climate change & 2 & 4.8 & \\
1986-1990 & 5 & 9.6 & \\
1991-1995 & 13 & 26.2 & \\
1996-2000 & 5 & 9.6 & \\
2001-2005 & 26 & 50.0 & 2002 \\
2006-2010 & & & \\
When thought the climate started & 7 & 14.3 & \\
changing & 24 & 46.4 & \\
1993-1997 & 20 & 39.3 & \\
1998-2002 & & &
\end{tabular}

Source: Field survey, July 2011 


\section{Sources of information on climate change First source of information on climate change}

Figure 1 shows that $21.6 \%$ of the respondent's sourced information on climate change first from television while $13.7 \%$ of them sourced from meteorologists. Other first sources of information on climate change were experience (5.9), story/ news $(3.9 \%)$, newspapers $(3.9 \%)$ schools $(3.9 \%)$. This finding shows that the respondents sourced information on climate change first from different sources and more importantly outside ADP. Hence it contradicts the study carried out by Sturges and Chimseu (1996) who opined that sources of information from outside the immediate system are very infrequent for the extension workers.

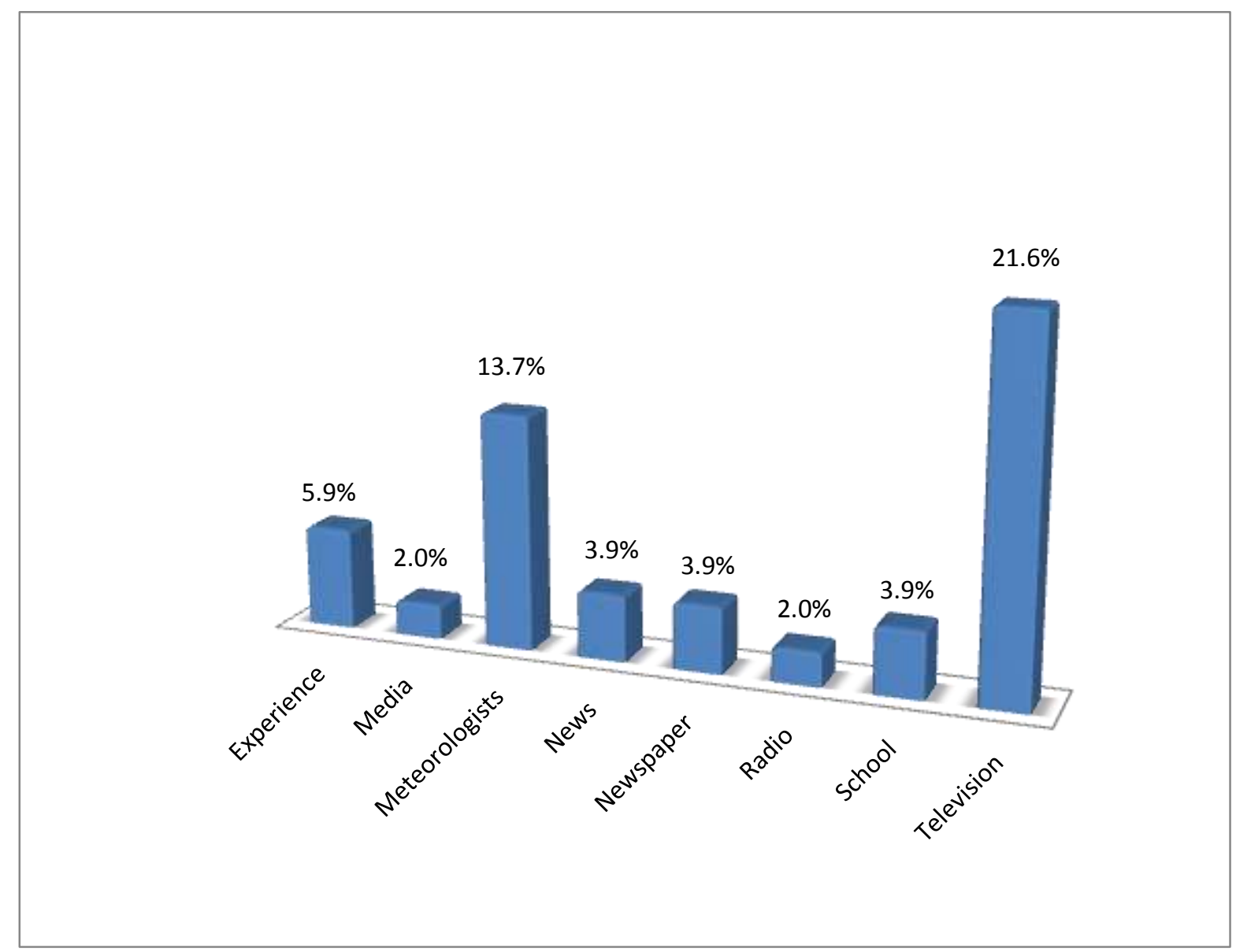

Figure 1: Respondent's first sources of information on climate change

\section{Sources of information on climate change}

Results in Table 2 show that the respondents' sourced information on climate change mainly from radio $(96.1 \%)$, fellow extension workers $(77.8 \%)$, television $(77.1 \%)$, newspapers $(76.6 \%)$, friends / relations $(56.5 \%)$ and forthnightly training 
(56.1\%). This finding shows that extension workers sourced information on climate change from both formal and informal sources. This can be appreciated because information they sourced informally can be authenticated by formal ones thereby giving them confidence on what they know about climate change and what they will eventually teach farmers about it.

TABLE 2

Respondents sources of information on climate change

\begin{tabular}{lcc}
\hline Sources $^{*}$ & Frequency & Percentage (\%) \\
\hline Radio & 49 & 96.1 \\
Fellow extension workers & 40 & 77.8 \\
Television & 39 & 77.1 \\
Newspapers & 39 & 76.6 \\
Friends/ relations & 29 & 56.5 \\
Fortnightly training & 29 & 56.1 \\
Monthly training review meeting & 25 & 48.8 \\
Workshops/seminars/training & 24 & 48.0 \\
Ministry of agriculture & 22 & 43.1 \\
Family members & 19 & 37.8 \\
Self initiative & 16 & 31.9 \\
Text messages from different networks & 15 & 29.8 \\
Town crier/ village/ town meeting & 12 & 23.9 \\
Tertiary school children & 9 & 16.7 \\
Telephone calls & 8 & 16.3 \\
Computer/e-mail & 8 & 16.3 \\
Primary/secondary school children & 7 & 13.3 \\
\hline
\end{tabular}

*-multiple responses

Source: Field survey, July 2011

\section{Activities occurring/undertaken by extension workers with respect to climate change}

The findings show that only 'extension workers now give their reports with reference to climate or weather of the environment' (58.8\%) was major activity occurring/ undertaken by extension workers with respect to climate change (Table $3)$. This activity has been in the system long ago thus showing that extension workers are yet to undertake sufficient activities that will equip, help and make them respond to climate change. Other minor activities the respondents were engaged with respect to climate change were extension workers disseminate information on climate/ climate related matters to the farmers (38.8\%) and availablility of weather/ climate measuring equipments in ADP (13.7\%). 
TABLE 3

Activities occurring/undertaken by extension workers with respect to climate change

\begin{tabular}{lll}
\hline Activities* $^{*}$ & Frequency & $\begin{array}{l}\text { Percentage } \\
(\%)\end{array}$ \\
\hline $\begin{array}{l}\text { Extension workers now give their reports with } \\
\text { reference to climate or weather of the environment }\end{array}$ & 30 & 58.8 \\
$\begin{array}{l}\text { Extension workers disseminate information on } \\
\text { climate/ climate related matters to the farmers }\end{array}$ & 20 & 38.8 \\
$\begin{array}{l}\text { Weather/ climate measuring equipments are now } \\
\text { available in the ADP }\end{array}$ & 7 & 13.7 \\
$\begin{array}{l}\text { Meteorologists/ weather forecasters are now } \\
\text { recruited in ADP }\end{array}$ & 7 & 12.8 \\
$\begin{array}{l}\text { ADP bulletin/ publication contain weather/ climate } \\
\text { related events }\end{array}$ & 5 & 9.8 \\
$\begin{array}{l}\text { Extension workers embarked on formal/ certificate } \\
\text { training on weather/ climate related courses }\end{array}$ & 3 & 5.9 \\
$\begin{array}{l}\text { Weather/ climate measuring equipments are now } \\
\text { used in the ADP }\end{array}$ & 2 & 3.9 \\
$\begin{array}{l}\text { Extension workers organize/ attend training/ } \\
\text { workshop/ seminar on climate and climate change }\end{array}$ & 2 & 3.9 \\
\hline
\end{tabular}

*-multiple responses Source: Field survey, July 2011

\section{Areas respondents needed training on climate /climate change issues}

Data in Table 4 show that areas respondents needed training on climate /climate change issues were prediction/forecasting of weather (92.2\%), acquisition/ management of weather equipment $(90.2 \%)$, adaptive strategies to climate change $(90.2 \%)$, measurement of intensity of sunshine $(90.2 \%)$, mitigation strategies to climate change $(90.2 \%)$, measurement of amount of rainfall $(84.3 \%)$, measurement of speed of wind (84.3\%) and formal degree certificate on climate change/climate related courses $(72.5 \%)$. This shows that extension workers need training on climate change and climate related issues so that they can respond, adapt to climate change and help farmers to do the same. Thus Agbamu (2005) has pointed out that one of the problems faced by extension workers in Nigeria is lack of training opportunities which may invariably affect training on climate change/ climate related courses. 
TABLE 4

Areas respondents need training on climate/ climate change issues

\begin{tabular}{lll}
\hline Training needs $^{*}$ & Frequency & $\begin{array}{l}\text { Percentage } \\
\text { (\%) }\end{array}$ \\
\hline Prediction/ forecasting of weather & 47 & 92.2 \\
Acquisition/ management of weather equipment & 46 & 90.2 \\
Measurement of intensity of sunshine & 46 & 90.2 \\
Adaptive strategies to climate change & 46 & 90.2 \\
Mitigation strategies for climate change & 46 & 90.2 \\
Measurement of amount of rainfall & 43 & 84.3 \\
Measurement of speed of wind & 43 & 84.3 \\
$\begin{array}{l}\text { Formal degree certificate on climate change/climate } \\
\text { related courses }\end{array}$ & 37 & 72.5
\end{tabular}

${ }^{*}$ multiple responses Source: field survey, July 2011

\section{Constraints limiting extension workers from responding to climate change}

Table 5 show that all the factors in the table were indicated as major constraints limiting extension workers from responding to climate change. The respondents indicated inadequate funding of the ADP by the Government $(M=3.4)$, no training on climate during FNT ( $M=3.4)$, lack of instruments for measuring weather/ climate in the ADP $(M=3.4)$, lack of well defined program $(M=3.3)$, absence of meteorologists/weather forecast specialist in the ADP $(M=3.3)$, poor training on climate during FNT $(M=3.2)$, poor training on climate during MTRM $(M=3.2)$, lack of adequate linkage to research $(M=3.2)$, no training on climate during MTRM $(M=$ 3.2), no information from research related to climate $(M=2.9)$, heavy workload/ inadequate number of extension workers in the system $(M=2.8)$ and poor remuneration of extension workers $(\mathrm{M}=2.81)$, as major constraints limiting extension workers from responding to climate change. 
TABLE 5

\section{Mean distribution of constraints limiting extension workers from responding to climate change}

\begin{tabular}{lcc}
\hline Variable & Mean & Standard deviation \\
\hline Lack of well defined program & 3.3 & 0.9 \\
$\begin{array}{l}\text { Inadequate funding of the ADP by the } \\
\text { Government }\end{array}$ & 3.4 & 0.8 \\
$\begin{array}{l}\text { Lack of adequate linkage to research } \\
\text { institutes especially meteorological }\end{array}$ & 3.2 & 0.7 \\
stations & & \\
$\begin{array}{l}\text { Poor training on climate during FNT } \\
\text { No training on climate during FNT }\end{array}$ & 3.2 & 0.9 \\
$\begin{array}{l}\text { Poor training on climate during MTRM } \\
\text { No training on climate during MTRM }\end{array}$ & 3.4 & 1.0 \\
$\begin{array}{l}\text { Lack of instruments for measuring } \\
\text { weather/ climate in the ADP }\end{array}$ & 3.2 & 1.1 \\
$\begin{array}{l}\text { Absence of meteorologists/weather } \\
\text { forecast specialist in the ADP }\end{array}$ & 3.4 & 1.2 \\
$\begin{array}{l}\text { Heavy workload/ inadequate number of } \\
\text { extension workers in the system }\end{array}$ & 2.8 & 0.9 \\
$\begin{array}{l}\text { Poor remuneration of extension } \\
\text { workers }\end{array}$ & 2.8 & 0.9 \\
$\begin{array}{l}\text { No information from research related to } \\
\text { climate }\end{array}$ & 3.0 & 0.9 \\
\hline
\end{tabular}

Source: field survey, July 2011

\section{Factors constraining extension workers from responding to climate change}

Table 6 shows that manpower development/ training, financial/ linkage and staff incentive problems were factors constraining extension workers from responding to climate change. Factors that loaded high under manpower development/ training problem were: poor training on climate during FNT $(0.90)$, no training on climate during FNT (0.93), poor training on climate during MTRM (0.96), no training on climate during MTRM (0.93), absence of a meteorologist in the ADP 
(0.62) and no information from research related to the area (climate change) (0.71). Factors that loaded high under financial/ linkage problem were: lack of adequate funding of ADP by the government (0.90) and lack of adequate linkage to research institutes especially meteorological stations (0.89). Factors that loaded high under staff incentive problem were: heavy workload/ inadequate number of extension workers in the system (0.95) and poor remuneration of extension workers (0.92).

This finding is in line with the work carried out by Agbamu (2005) who opined that agriculture development system in Nigeria generally faces the problems of insufficient funds, limited number of trained human resources, lack of training opportunities, inappropriate salary scales and promotional prospects. These problems invariably affect their responses to climate change. 
TABLE 6

Factor analysis of the constraints limiting extension from responding to climate change

\begin{tabular}{|c|c|c|c|}
\hline Constraints & $\begin{array}{l}\text { Factor 1: } \\
\text { Manpower } \\
\text { development/ } \\
\text { training } \\
\text { problem }\end{array}$ & $\begin{array}{l}\text { Factor 2: } \\
\text { Institutional/ } \\
\text { Linkage } \\
\text { Problem }\end{array}$ & $\begin{array}{l}\text { Factor 3: } \\
\text { Staff } \\
\text { Incentive } \\
\text { problem }\end{array}$ \\
\hline Lack of well defined program & 0.62 & 0.57 & 0.23 \\
\hline $\begin{array}{l}\text { Lack of adequate funding of ADP by } \\
\text { the government }\end{array}$ & 0.27 & 0.90 & 0.02 \\
\hline $\begin{array}{l}\text { Lack of adequate linkage to research } \\
\text { institutes especially meteorological } \\
\text { station }\end{array}$ & 0.25 & 0.89 & -0.03 \\
\hline Poor training on climate during FNT & 0.90 & 0.25 & 0.12 \\
\hline No training on climate during FNT & 0.93 & 0.30 & -0.11 \\
\hline Poor training on climate during MTRM & 0.96 & 0.16 & 0.01 \\
\hline No training on climate during MTRM & 0.93 & 0.25 & -0.16 \\
\hline $\begin{array}{l}\text { Lack of instruments for measuring } \\
\text { weather/ climate in the ADP }\end{array}$ & 0.55 & 0.53 & 0.49 \\
\hline $\begin{array}{l}\text { Absence of a meteorologist (weather } \\
\text { forecast specialist) in the ADP }\end{array}$ & 0.62 & 0.32 & 0.37 \\
\hline $\begin{array}{l}\text { Heavy workload/ inadequate number } \\
\text { of extension workers in the system }\end{array}$ & -0.01 & -0.02 & 0.95 \\
\hline $\begin{array}{l}\text { Poor remuneration of extension } \\
\text { workers }\end{array}$ & 0.05 & 0.04 & 0.92 \\
\hline $\begin{array}{l}\text { No information from research related } \\
\text { to the area }\end{array}$ & 0.71 & 0.22 & 0.29 \\
\hline
\end{tabular}

Source: field survey, July 2011 


\section{Conclusion}

Based on the finding of the study, the following conclusions were made:

1. All the respondents have heard about climate change and this was shortly after they noticed it.

2. Respondent's sourced information on climate change from both formal and informal sources.

3. There was little or no change/activity undertaken by the respondents with respect to climate change.

4. Respondents needed training on climate change and climate related issues.

5. Manpower development/training, financial/linkage and staff incentive problems were constraints limiting extension workers from responding to climate change.

\section{Recommendations}

Based on the major findings of this work, the following recommendations were made:

1. There is need to include climate change and climate related issues into the programme of agricultural extension through ADP since it is a global fact threatening agriculture. In this way, extension workers especially extension agents will be acquainted with more facts about climate change. They will then acquaint their clientele with the knowledge thereby proffering solution to the problems of climate change the farmers face.

2. Frequent seminars/ workshops should be organized in and by Ministry of agriculture/ADP and extension workers should be given the privilege to attend workshops/seminars organized by governmental and nongovernmental organizations on climate related issues so that they can acquire more skills and techniques to face challenges of climate change.

3. Government should provide weather measuring equipments to ministry of agriculture and ADP. Meteorologists should be recruited to handle these equipments and educate extension workers and farmers on its use and other weather related facts. 
4. Government should offer scholarship for in-service training of extension workers on climate change and climate related issues. This will enlighten the extension workers, harness their knowledge on climate and climate change and enable them acquire competence in handling, measuring and prediction of weather/ climate. This competence especially in prediction of weather will invariably help in development of favourable work plan for agriculture, improvement of agriculture as well as growth and development of the entire nation.

\section{References}

Agwu A.E and Adeniran A.A (2009). Sources of agricultural information used by arable crop farmers in Isale Osun Farm Settlement, Osogbo Local Government Area of Osun State, Journal of Agricultural Extension Vol. 13(1), pp. 24-34

Agbamu, J. U. (2005). Problems and prospects of agricultural extension service in developing countries. In S.F. Adedoyin (Ed). Agricultural Extension in Nigeria. ARMTI, Ilorin. AESON. Issue( 2), pp. 52-62

Apata T.G., Samuel, K.D., and Adeola, A.O, (2009). Analysis of Climate Change Perception and Adaptation among Arable Food Crop Farmers in South Western Nigeria. Contributed Paper prepared for presentation at the International Association of Agricultural Economists' 2009 Conference, Beijing, China, August 16-22, 2009

Ayanwuyi, E Kuponiyi, F.A Ogunlade, Oyetoro J. O (2010). Farmers perception of impact of climate changes on food crop production in ogbomosho agricultural zone of Oyo state, Nigeria in Global Journal of Human Social Science vol. 10 (7), pp. 33-39

Botkin D. and Keller E. (2000) Environmental Science: Earth as a Living Planet. Danvers, MA: John Wiley \& Sons, Inc.

Building Nigeria's Response to Climate Change (BNRCC), (2008): 2008 Annual Workshop of Nigerian Environmental Study Team (NEST): The Recent Global and Local Action on Climate Change, held at Hotel Millennium, Abuja, Nigeria; 8-9th October, 2008.

Comrey (1962) in chukwuone, N.A., Agwu, A.E and Ozor, N. (2006) Constraints and strategies towards effective cost sharing of agricultural technology delivery in Nigeria: Perception of farmers and agricultural extension personal. Journal of International Agricultural and Extension Education 13 (1) $29-40$.

Ekpoh, I. J. (2009). Environmental knowledge, awareness and concern among 11th grade students in New York State Journal of Climate, society and environment, vol 24 issue 1 pp 27-34. St. Paul publishing co. New York. 
Fischlin, A., G.F. Midgley, J.T. Price, R. Leemans, B. Gopal, C. Turley, M.D.A. Rounsevell, O.P. Dube, J. Tarazona, A.A. Velichko, (2007): Ecosystems, their properties, goods, and services. Climate Change 2007: Impacts, Adaptation and Vulnerability. Contribution of Working Group II to the Fourth Assessment Report of the Intergovernmental Panel on Climate Change, M.L. Parry, O.F. Canziani, J.P. Palutikof, P.J. van der Linden and C.E. Hanson, Eds., Cambridge University Press, Cambridge, pp 211-272.

Hulme, M., Doherty, R., Ngara, T., New, M. and Lister, D. (2001) African climate change: 1900-2100 in Climate Research vol 17, pp 145-168.

Intergovernmental panel on climate change (IPCC) (2007) Climate change impacts, Adaptation and vulnerability in Third Assessment Report of the Intergovernmental Panel on Climate Change Parry, M. L. Canziani, O. F. Palutikof, J. P, Vanderlinden, P. J, and Hasson (eds), C. E. Cambridge University Press, Cambridge, United Kingdom pp. 80-96.

Kurukulasuriya, P. Mendelsohn, R. Hassan, R, Benhin, J. Deressa, T. Dip. M. Fosu, K. Y. Jain, S. Mano, R. Molua E. Ouda, S. Sene, I, Seo S. N. and Dinar, A. (2006) Will African agriculture survive climate change? World Bank Economic Review vol 20 issue 3 pp 67-88.

Mowa, E. L. and Lambi, C. M. (2007) Economic Impact of Climate change on agriculture in Cameroon, Policy Research paper No 4364 World Bank, Washington, D. C.pp. 51-55.

National Population Commission (NPC), (2006) National population census 2006. Abuja, Nigeria.

Odjugo, P.A.O (2008): Quantifying the cost of Climate Change Impact in Nigeria: Emphasis on Wind and Rainstorms 50th Annual Conference-Book of proceedings. Index Books Ltd, Calabar. Pp 93-101

Parry, M.L., Canziani, O.F. Palutikof, J.P. van der Linden, P.J. and C.E. Hanson, (2007). Climate Change: Impacts, Adaptation and Vulnerability. Contribution of Working Group II to the Fourth Assessment Report of the Intergovernmental Panel on Climate Change" - Annex I., Cambridge University Press, Cambridge, UK,

Rudolf, W. Hermann, W. (2009) Climate risk and farming Systems in Rural Cameroon. Institute of Development and Agricultural Economics. University of Hannover, Germany. 
Schneider, S.H., S. Semenov, A. Patwardhan, I. Burton, C.H.D. Magadza, M. Oppenheimer, A.B. Pittock, A. Rahman, J.B. Smith, A. Suarez and F. Yamin, (2007): Assessing key vulnerabilities and the risk from climate change. M.L. Parry, O.F. Canziani, J.P. Palutikof, P.J. van der Linden and C.E. Hanson, (Eds) Climate Change 2007: Impacts, Adaptation and Vulnerability. Contribution of Working Group II to the Fourth Assessment Report of the Intergovernmental Panel on Climate Change, Cambridge University Press, Cambridge, UK, 779-810.

Smith, B. and Skinner, M. (2002) Adaptation options in Agriculture to climate change: A typology, mitigation and Adaptation Strategies for Global Change African Journal of Agriculture and Resource Economics vol 3 issue 5 pp. 78-82.

Sturges P. and Chimseu G. (1996). The chain of information provision in the villages of Malawi: A rapid rural appraisal. International Information and Library Review 28, 135-156

Union of concerned scientists(UCS) (2002). Confronting climate change in the Gulf Coast Region. Accessed from http://www.ucsusa;org/cssets/documents global warming/ucs guilt curriculum. pdf. on 09/4/2011. 